\title{
Dr hab. Janusz Andrzej Drob, prof. KUL (ur. 12 lutego 1952, zm. 3 lutego 2011)
}

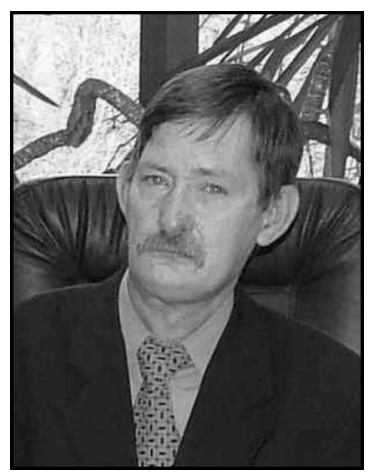

Profesor dr hab. Janusz Andrzej Drob zmarł nieoczekiwanie w pełni sił twórczych.

Urodził się w Cycowie w województwie lubelskim. W latach 1973-77 podjął studia historyczne na Sekcji Historii Wydziału Nauk Humanistycznych Katolickiego Uniwersytetu Lubelskiego. Po uzyskaniu tytułu magistra rozpoczął pracę w Sekcji Historii (obecnie Instytut) w Katedrze Historii Kultury Polskiej. W Instytucie Historii tejże uczelni przeszedł całą drogę zawodową jako pracownik naukowy i dydaktyczny, od asystenta do profesora nadzwyczajnego. W roku 1985 uzyskał tytuł doktora. Następnie w roku 1998 uzyskał tytuł profesora KUL.

Od roku 1999 prof. Janusz Drob pełnił funkcję Dziekana Wydziału Nauk Humanistycznych KUL przez trzy kadencje. W tym czasie Wydział znacznie się rozwinął, pojawiły się także nowe kierunki studiów. Profesor zdobył wielki szacunek oraz sympatię zarówno w gronie studentów, jak i kadry dydaktycznej KUL. Od roku 2002 pełnił także funkcję Kierownika Katedry Historii XVI-XVIII wieku w Instytucie Historii. Profesor traktował swe obowiazki na uczelni z właściwą sobie rzetelnością. Tematy prac magisterskich podejmowanych przez grono uczniów niewątpliwie znajdowały odzwierciedlenie w Jego własnych zainteresowaniach badawczych. W kontaktach ze studentami i współpracownikami był zawsze pomocny, życzliwy, chętnie udzielający swych mądrych rad i sugestii.

Profesor Janusz Drob swoje doświadczenie zawodowe zdobywał zarówno w kraju, jak i za granicą. Swą wiedzę poszerzał poprzez wyjazdy na stypendia naukowe do Belgii w Katolickim Uniwersytecie w Leuven (1978 rok). W latach 1985-1987 był uczestnikiem programu Scuola Storica Italo-Polacca w Rzymie. Był także na stypendium naukowym w Paryżu (1988 roku), a w 1990 roku przebywał na stypendium Fundacji Lanckorońskich w Rzymie. Ś.p Janusz Drob był także w czasach PRL aktywnym uczestnikiem oporu społecznego, współpracując z podziemnym czasopismem młodych katolików „Spotkania”, za co otrzymał w roku 2001 odznakę Zasłużonego Działacza Kultury. W 2005 roku został 
odznaczony Srebrnym Krzyżem Zasługi. Pośmiertnie został odznaczony także Krzyżem Kawalerskim Orderu Odrodzenia Polski przez Prezydenta Bronisława Komorowskiego. Był autorem wielu prac historycznych, z których wymienię jedynie niektóre: Model człowieka wieku XVII w kazaniach Berarda Gutowskiego, Obieg informacji $w$ Europie $w$ pot. XVII wieku w świetle drukowanych i rękopiśmiennych gazet $w$ zbiorach watykańskich, Trzy zegary: obraz czasu i przestrzeni w polskich kazaniach barokowych. Był także autorem podręcznika do gimnazjum pt.: Historia - podręcznik, gimnazjum, klasa 2. Czasy nowożytne. Zainteresowania Profesora skupiały się wokół historii kultury nowożytnej, a także informacji i dyplomacji w Europie XVI-XVIII wieku.

$\mathrm{Z}$ wielkim trudem przychodzi pisać o Profesorze Januszu Drobie w czasie przeszłym, nie tylko jako uczonym, ale przede wszystkim jako człowieku, który będąc otwartym na innych, obdarzał ludzi ciepłym, życzliwym słowem i uśmiechem. Był człowiekim dyskretnycm i skromnym w najszlachetniejszym tego słowa znaczeniu.

Monika Krajewska

Lublin 